\title{
Morphometric Characteristics of the Relief as a Premise in the Pedogenetic Process and Indirect Mapping of Soil Types in the Anieş Hydrographic Basin
}

\author{
Cornel NEGRUȘIER*, Ioan PĂCURAR \\ ${ }^{1}$ Faculty of Agricultural Sciences, University of Agricultural Sciences and Veterinary Medicine Mănăştur \\ St., No. 3 - 5,400372 Cluj-Napoca, Romania \\ * corresponding author: cornelnegrusier@gmail.com
}

Bulletin USAMV series Agriculture 72(1)/2015

Print ISSN 1843-5246; Electronic ISSN 1843-5386

DOI 10.15835/buasvmcn-agr: 11141

\begin{abstract}
Developed by a geological structure similar asymmetric horst, Anieş's morph-hydrographic basin presents through its relief forms, a complex geographical unit, in terms of morphometric indicators respectively altitude, slope, depth of fragmentation and slope exposition for the entire landscape. At a taxonomic level, we can distinguish a variety of soil types and subtypes, mainly due to the physical and chemical properties and mineralogical soil deposits. This article aims to interpret some morphometric indicators and correlations supported by a GIS raster and vector database integrated in spatial analysis modules, discover quantitative and qualitative features of various types of surfaces and define morphometric parameters. The morphometric study of: slope, slope exposition and energy relief correlated with altitude by indirect mapping, have identified the following types of zone soils: luvisols, eutric cambosols distric cambosols, podzols, prepodzols, criptopodzols and humosiosols and intra-zone soils: rendzins, lithosols, hystosols and fluvisols. The indirect maping reflect the variety and complexity of soil types in Anieş's basin, each with varying surfaces, lithological substrates and specific properties The necessity of this article is important in the achievement of studies concerning the land usefulness, in order to implement essential measures such as: correcting the soil's acidity and monitoring the lands affected by soil erosion.
\end{abstract}

Keywords: Anies basin, GIS concept, morphometric features, soil

\section{INTRODUCTION}

Situated in the North-East of the Bistrita Nasaud County, Anies basin (13,465 ha) overlaps with the geographical and morphological contact area of Rodna Mountains. It consists mainly of crystalline schists arranged in 2 series: the mezometamorphic series of Bretila and the epimetamorphic series of Repedea, that is added on different areas spread with crystalline limestone, amphibolites and volcanic formations which paint a unique landscape.
From an evolution and altimetric point of view, Anieș is an epigenetic type of valley, deepening continuously in sedimentary and crystalline schists, which took place simultaneously with the formation of Rodna massif and the network installation of Somesul Mare river.

The basin's shape is almost triangular, creates a relief with steep slopes and fragmented valleys densities, and acts as a recipient of matter and energy entering Somes's fluvial system. 


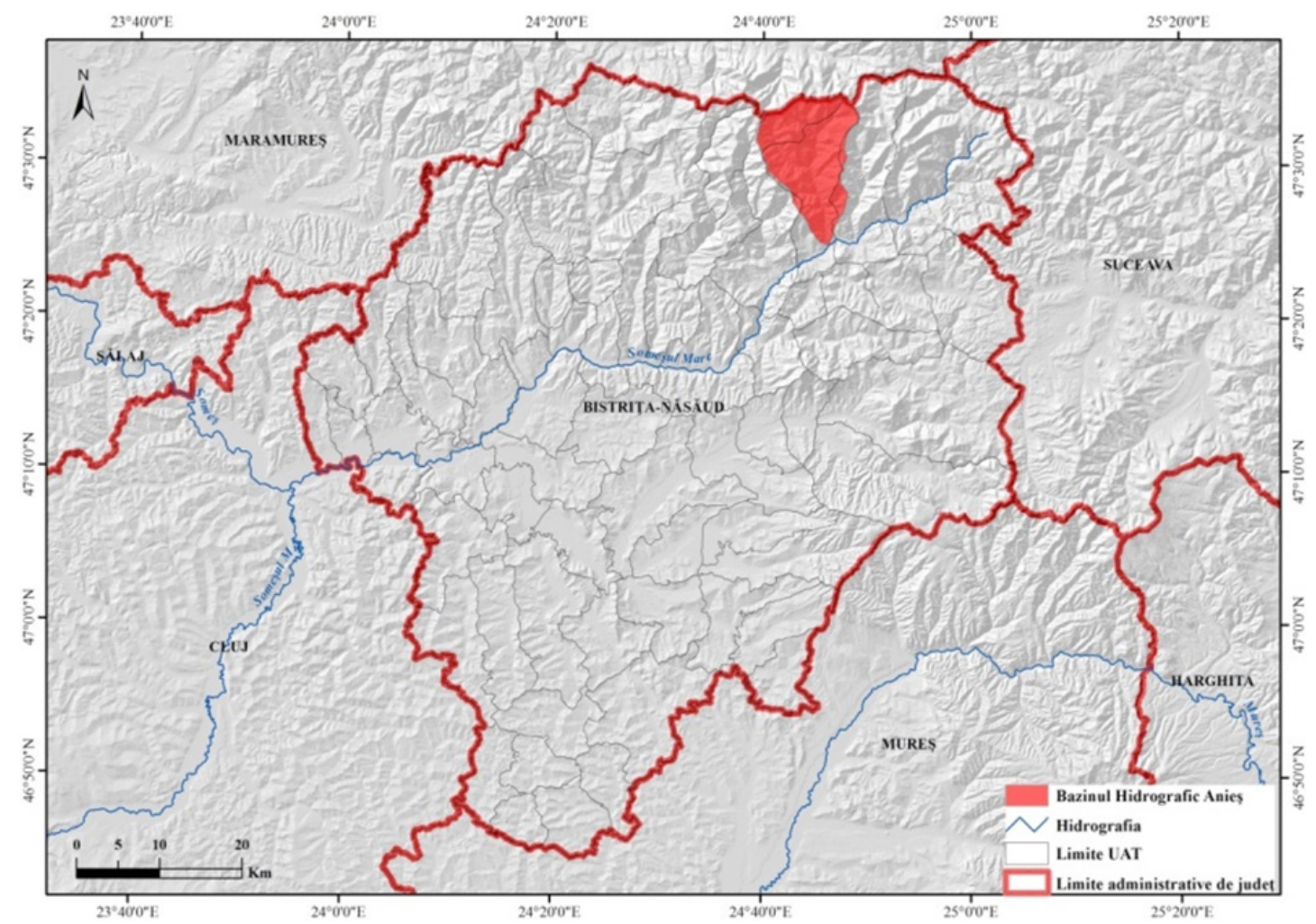

Fig.1. The geographic position of Anies basin

The soil and the soil cover are considered as a balance of geomorphological actions that hold soil formation and pedogenesis processes (Schelling 1970, Florea 2003), the relief being inseparable from the soil cover, they evolved together, thus we can determine the rate of evolution and the development stage through soil properties, water and air regime, vegetation and microclimate. (Pacurar et al. 2012).

Therefore regional characteristics of the soil cover are the result of morphometric factors slope, relief energy and slope exposition, to which we add the altitude as a main factor that paints the vertical zoning of soil types.

Regional character is given by geological and geomorphological factors based on the first category, and the topological character comes as a result of the two acting categories of factors that take local differentiated forms, depending on the various elements of relief and diverse categories of parental material.

\section{MATERIALS AND METHODS}

The present scientific approach represent the identification of the main factors and the morphometric study in the pedogenesis premise and indirect mapping of the main soil types present in Anieș Basin.

Analysis of morphometric factors: slope, relief energy, slope exposition have been performed according to the instructions issued by the ICPA Bucharest "A Development methodology of soil studies" (vol. III). In the altitudinal zoning, the distribution of forest vegetation and soil cover, in the form of parallel strips succeeding and replacing each other, were taken into account (Pacurar. 2005).

The main thematic maps - map of slopes, relief energy, orientation slopes and, altitudes were performed using GIS techniques and spatial analysis. Primary databases in the spatial analysis process are in the format of vector and raster (MDE $20 \times 20 \mathrm{~m}$, hydro-graphic network, relief unit limits geology), derivatives (slope, slope exposition, altitude) and modelled relief energy.

Based upon the cartographic database and by using quantitative information extracted in the analysis phase about the studied area, the main regional and azonic soil types have been identified and a short characterization has been made of their properties and spatial distribution, in relation to the morphometric factors. 
Tab.1. Database structure

\begin{tabular}{ccccc}
\hline Nr crt & Name & Type & Origin & Atribute \\
\hline 1 & MDE & Raster & Primary & Altitude \\
\hline 2 & Hydrography & Vector & Primary & Hydrographic network \\
\hline 3 & Relief limit & Vector & Primary & Name of relief limit \\
\hline 4 & Geology & Vector & Primary & Geology \\
\hline 5 & Slope & Raster & Derivate & Slope \\
\hline 6 & Slope exposition & Raster & Derivate & Orientation type \\
\hline 7 & Altitude & Raster & Primary & Altitude \\
\hline 8 & Relief energy & Raster & Modelled & Depth value \\
\hline
\end{tabular}

\section{RESULTS AND DISCUSSION}

Geomorphological processes are relief shapers that are involved significantly in pedogenetic; as a consequence of this the soil cover appears more varied, both in terms of stage development and soil type and also in terms of mineral substrate. By inclining and slope exposition of the basin, we individualise combinations of dominant soils in the soil cover, which represent their specific features.

Baize (1986) and Soil Survey Manual (1993) point out that slope, slope exposition, relief energy and altitude should be considered essential characters of soil cover, sedentary characters or "ecological station", believed to be as important as constitutional and organisational soil characters, because they both influence pedogenetic and geo-morphogenesis, but also drainage and soil functionality, determining the conditions and restrictions of the soil cover usage.

The morphometric factors: slope, slope exposition and relief energy, present the following quantitative parameters, adapted from “Development methodology soil studies (1987).

\section{Slope shape}

The slope is an essential parameter to quantify, in quantitative terms as a developer factor of downhill processes and in qualitative terms as a generator factor of relief forms with geomorphological significance over characteristics of the soils covers (Bilasco et. al 2013).

According to development methodology studies, a classification of the soil's slope in six intervals of values is proposed, expressed as a percentage, and ranged: $0-1 \%$ practically horizontal, $1-2 \%$ extremely low angled, 2-5\% weak, $5-12 \%$ middle inclined, $12-20 \%$ strongly inclined, more than $20 \%$ very strongly inclined.

Regarding the surface examined and its different slope levels expressed in sexagesimal and centesimal degrees, most of the basin presents very strong inclined surfaces, with 10,067.84 ha holding approximately $75 \%$ of the total area, moderately inclined surfaces holding 2616.6 ha at a rate of $19.43 \%$ and only $4.84 \%$ for the weakly inclined at 653.04 ha. Low angled surfaces, generally located in Anies's floodplain, are represented by 128.04 ha in an insignificant proportion of $1 \%$.

Because of the $75 \%$ high inclined surfaces all pedogenetic processes are influenced, respectively the properties, dynamics and features of the entire soil surface and geomorphological processes belonging to a certain soil cover interfering with it.

Thus the slope directly influences the water and the circulation of soil substances, process that occurs from the dominant high peaks Galati, Omu, Gargalau, Puzdrele and Intre Izvoare, towards the low valleys Anieșul Mare, Anieșul Mic, Blidereasa, Tomnatec, draining both vertically and laterally.

\section{Relief energy}

The relief's energy or its fragmentation depth are expressions of difference in altitude between the lowest level, respectively the valley bed, and the highest level, namely the peaks of a complex; and this was calculated by classical methodology, calculating the difference between extreme points, values expressed in meters.

Fragmentation depth directly influences the soil cover on the morpho-hydrographic basin. A high value area of vertical fragmentation induces a restriction of soils spread and pedogenetic processes. 
The analysis of the energy map shows that $26.54 \%$ of the basin registers values contained in the interval $>500 \mathrm{~m} / \mathrm{kmp}$, areas with very high depth found predominantly in the high mountain and valley corridors upstream.

Areas with high-energy values 301-500 m/ kmp represent $65.10 \%$, distributed in all relief levels, that indicate asymmetric distribution of the soil's substrate according to lithology.

A percentage of $7.44 \%$ of the total area represent the interval $151-300 \mathrm{~m} / \mathrm{kmp}$ mediumdepth, followed by only $1 \%$ with small depth $0-150 \mathrm{~m} / \mathrm{kmp}$.

Small values of drainage are a characteristic for high mountain plateaus - Gargalau, Omu, surfaces generally located at the confluence of the following streams Anieș Mare - Anieș Mic - Dealul Secii and Izvorul Mare - Izvorul Butuci.

Water and substances circulation occurs more dynamic, especially by surface draining. Often associated with landslides on deforested lands, causing a significant movement of material from the upper to the lower parts, the soil then being carried by the rivers. By depletive-accumulative circulation, a soil cover difference of lithological geochemical order is produced. The soil cover shows a varied assemblage consisting of sequences of different soil thickness, acidity, texture, frame content and degree of development.

\section{Slopes exposition}

Represents an important quality parameter in current modelling of the slopes within the Anies basin.

The general and the slope exposition type depends on the high density of hydrographic network, orientation courses from the source to shedding in Anies.

Through solar and caloric radiation, southern slopes are predominantly oriented and exposed to more disaggregation and alteration processes, compared to those oriented towards the north.

The basin surface is a mosaic of slope expositions close in spreading values. The general orientation of the basin is in the East-West

Tab.2. Characteristics of slope inclination fragmentation density and depth categories

\begin{tabular}{ccc}
\hline Slope inclination (\%) & Fragmentation density & Fragmentation depth (m) \\
\hline$<1$ & Extremely low angled & $<10$ \\
\hline$<2$ & Weakly inclined & $11-50$ \\
\hline $2.1-5$ & Weak & $151-30$ \\
\hline $5.1-12$ & Middle inclined & $301-500$ \\
\hline $12.1-20$ & Strongly inclined & $>500$ \\
\hline$>20$ & Very strongly inclined & \\
\hline
\end{tabular}

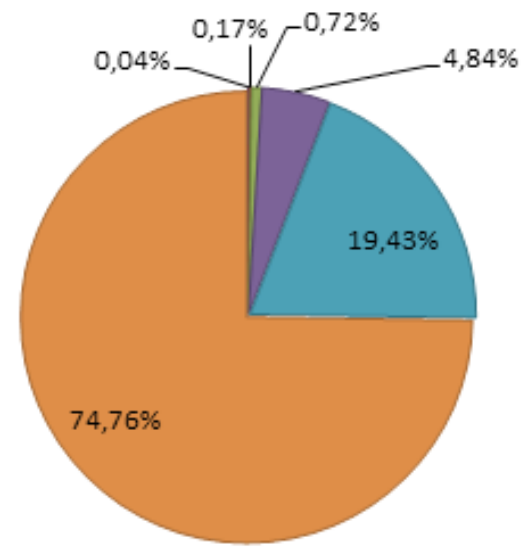

Fig.2. Slope Anies basin

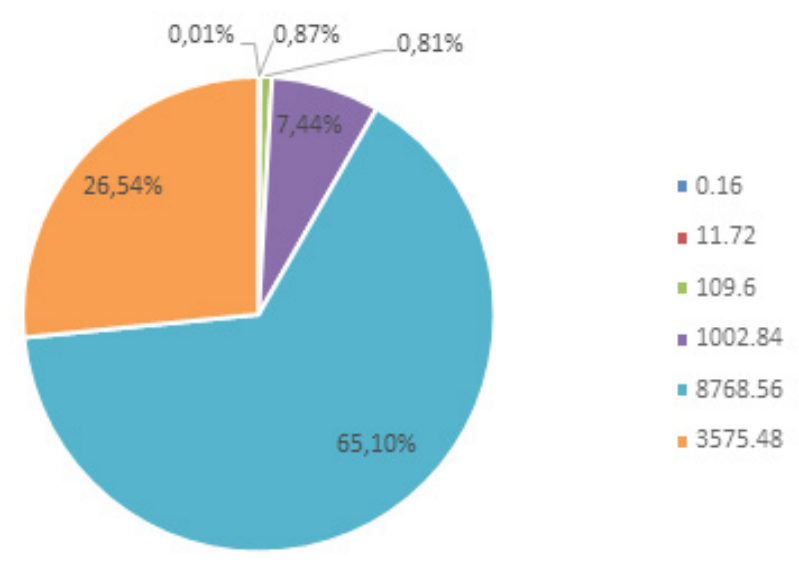

Fig.3. Slope map 
direction, which paints a territory of varied and consistent typology of the slopes.

By analysing surfaces with different types of expositions it is observed that the largest areas of slopes are found to be predominantly oriented towards East with about 28\%, South with 26\% and West with 24\%. Surfaces less extensive are Northern slopes' expositions with approximately $13 \%$.

Slope exposition influences the development of paedogenetic processes that induce changes in soil types and vegetation and their properties, by solar radiation and temperature that are irregularly distributed on the surface of the basin according to their exposition.

\section{Altitude}

Being a mountain basin, altitude is a defining morphometric element in shaping the soil cover, vegetation, human activities and land management in terms of suitability to different types of agriculture. Hypsometric identified, a minimum of $487 \mathrm{~m}$ elevation located in the Southern part of the

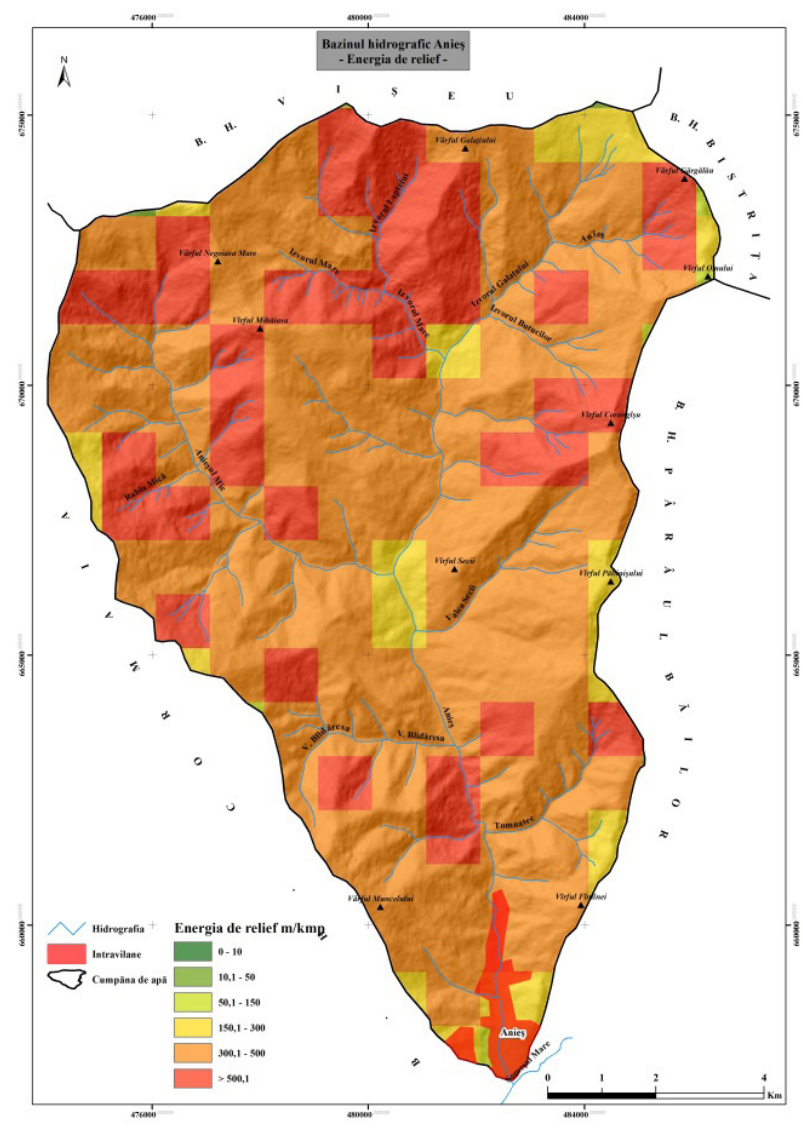

Fig.4. Relief energy map basin and a maximum rate of 2,250 in the North, cause an amplitude of $1763 \mathrm{~m}$.

According to Pacurar (2005) altitudinal zonality of forest vegetation and soil cover takes into account a distribution of soils in the form of relatively parallel strips that are subsequently replacing one to another.

By the analysis of the hypsometric map (Fig.8.) we can identify five distinct relief levels in varying proportions:

First level between $487 \mathrm{~m}-1000 \mathrm{~m}$, is identified on 4083 ha, characterized by low altitudes, including valleys and hills. On a layer of sedimentary and metamorphic rocks, we can meet eutric cambisols with sandy loam texture, with a rich basic flora at the surface, with dominant associations of Agrostis tenuis and Asperula odorata. Valleys meadows, we frequently meet fluvisols with natural vegetation consisting mainly of phytocoenosis with Alnus incana and Salix purpurea.

Second level between $1001 \mathrm{~m}-1300 \mathrm{~m}$ introduces the Fagus sylvatica vegetation floor, consisting approximately of 3852 ha, with

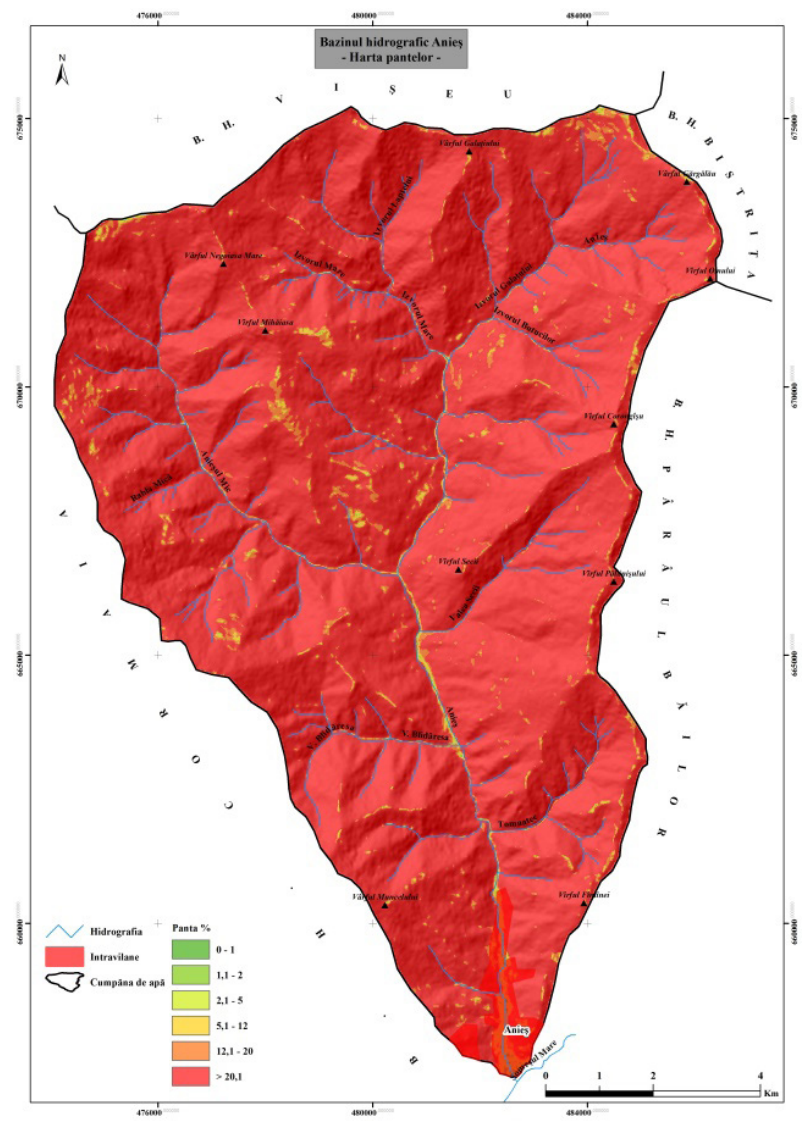

Fig.5. Relief energy Anies basin 
luvisols that are typically found on sedimentary rocks, sandstones and gravels, present often with an alternating distribution. The soil has a loamy texture, moderate reaction, low contentin nutrients and humus reserve. The vegetation is

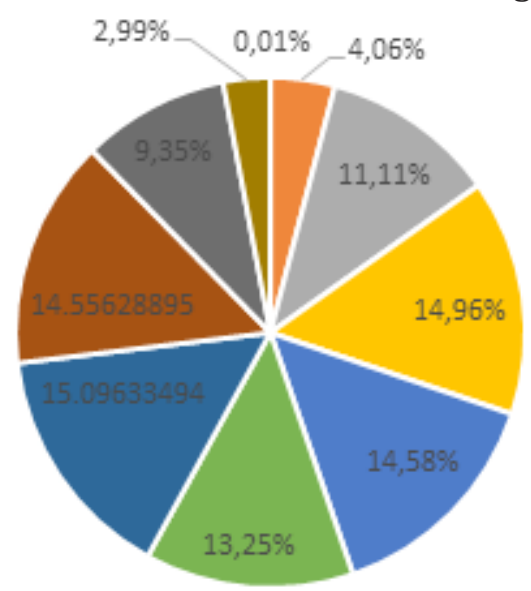

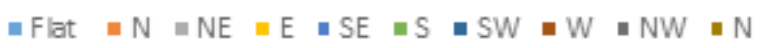

Fig.6. Slope exposition Anies basin

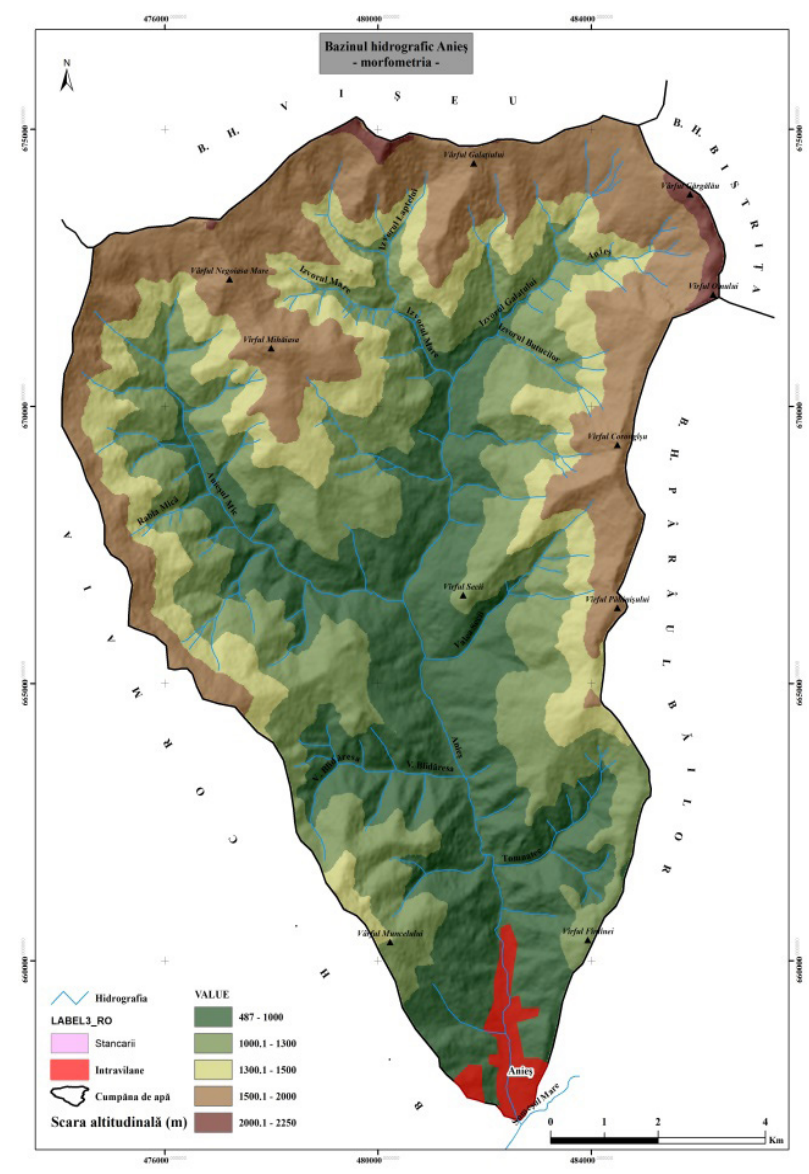

Fig.7. Slope exposition map varied, being composed by mixed forests (Fagus sylvatica, Acer pseudoplatanus, Fraxinus excelsior, Betula pendula) with a rich grassy cover made from species of Dentaria, Geranium, Allium gens.

Third level, between $1301 \mathrm{~m}-1500 \mathrm{~m}$ with an area of 2214 ha, is made of mixed forests floors with Picea abies, Abies alba and with a vegetation floor of Festuca rubra and Nardus stricta. Built predominantly on sedimentary rocks (sandstone, marls), where we especially meet distric cambisols, with a sandy loam texture, acid reaction and medium humus reserve.

Level four $1501 \mathrm{~m}$ - $2000 \mathrm{~m}$ area of 3184 ha, softwood floor with Ericaceae cover, the largest expansion accomplished by the prepodzols, criptopodsols and podzols, formed upon sericitechlorite schist, with loamy textures, strongly acidic nature, rich organic matter and poorly saturated in bases. On deforested lands, as herbaceous vegetation installs, these soils become more shallow and rich in acid humus.

At the high altitudes, on the land covered by short bushes (Rhododendron, Vaccinium) and Carex curvula, Juncus trifidus and Festuca airoides,

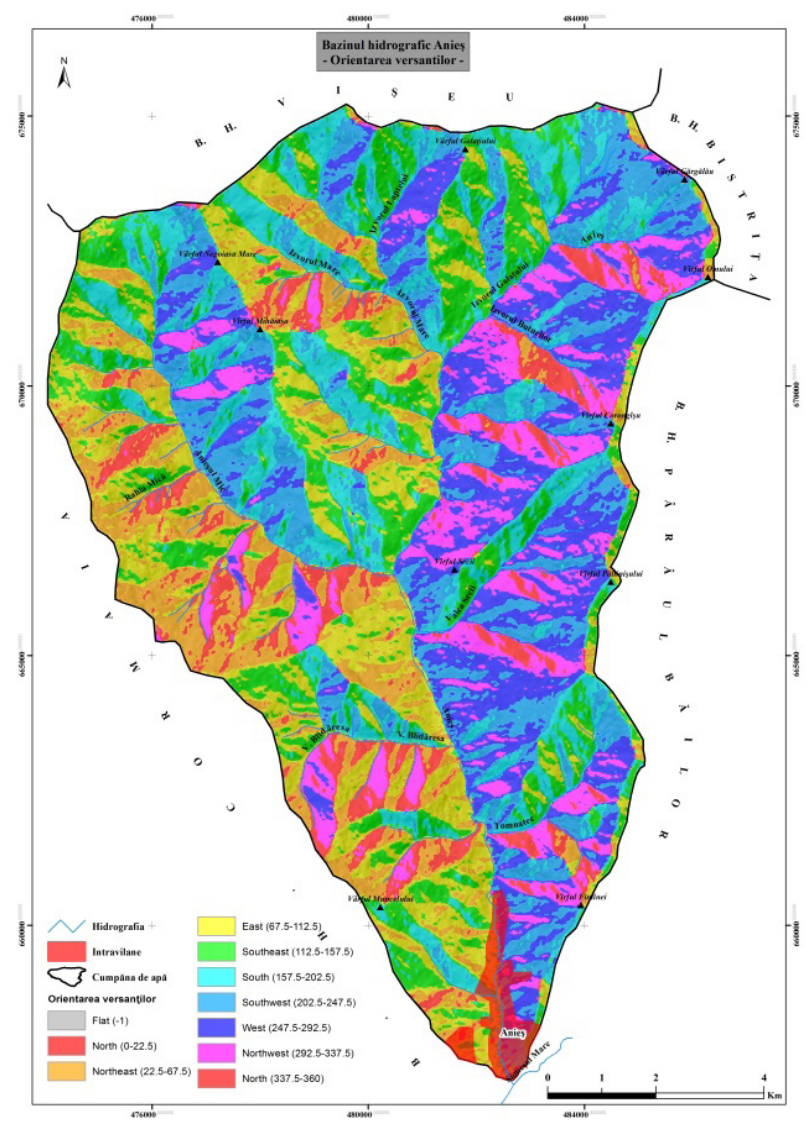

Fig.8. Altitude map 
primary meadows meet shallow humosiosols, with loamy texture, strongly acidic nature, rich in organic matter and poorly saturated in bases. This type of soil represents the main complementary pedoclimax alpine meadows. Histosoils fall into intra-zone soils group, developed on lands with excess moisture surrounded by water sources and subalpine streams, terrains that develop acid-phytocenosis belonging to Scheuchzeriocaricetea nigra's class.

Last level $2001 \mathrm{~m}$ - $2200 \mathrm{~m}$ area of 130 ha, under the juniper phytocenosis, we meet weak evolved lithosols, that develop on crystalline rocks, boulders and gravel, usually consolidated with a loamy texture, a strong acid reaction and a high percentage of organic matter. On the ridges and slopes peaks, rich in small detritus and active erosion, we meet lithosols under the alliance of Thlaspeion rotundifolii phytocenosis. Due to a varied fragmented relief, rendzins evolved under Festuco saxatilis - Sesleria bielzii phytocoenosis's alliance (Galati, Muntele Cailor, Corungis). These are shallow soils, with a neutral or slightly alkaline reaction, high carbon content and high percentage of humus.

\section{CONCLUSION}

The analysis of morphometric factors in the Anies basin shows a highly complex geomorphological relief, which relates differently to the various soil types, identified by indirect mapping.

The slope's relief analysis outlines two characteristic intervals for the entire surface of the Anies basin. First interval, measuring over $12^{\circ}$ correlates with high altitudes, and the second interval maps areas located within the range of $0-12^{\circ}$ along streams and high mountain plateaus.

High-energy values are identified in all catchment areas, both in the valleys and in the high mountain areas. Small energy overlaps insular areas present on the horizontal surfaces of the basin.

Southern and Eastern expositions characterize the entire surface of the basin. These slopes are exposed to pedogenetic processes. In the winter season, on Southern slopes, snow melt occurs rapidly, and in the summer season the slopes heat up very quickly and thus they easily lose water reserve. In conclusion, the Southern slopes present a hot and dry top climate, being exposed to such intense processes of disaggregation and alteration, with snow melt accumulated in a shorter time. It is also a quality restriction parameter for subsistence crops, and for installation and growth of forest vegetation; surfaces facing North or Northwest have a small suitability because the slopes are wet and cold.

The morphometric study of: slope, slope exposition and energy relief correlated with altitude by indirect mapping, have identified the following types of zone soils: Luvisols, Eutric cambosols distric cambosols, podzols, prepodzols , criptopodzols and humosiosols and intra-zone soils: rendzins, lithosols, hystosols and fluvisols.

The soil study reveals that Anies Basin is characterized by a variety of conditions of genesis, evolution, types, morphological characteristics, properties and spatial distribution of soils in interdependence or correlation with the territorial unit features. This specific is given by the combination of soils characteristics to the Rodna mountains relief forms as evolution and functionality.

Acknowledgments. This paper was published under the frame of European Social Fund, Human Resources Development Operational Programme 2007-2013, project no. POSDRU/159/1.5/ S/132765.

\section{REFERENCES}

1. Baize D (1986). Couvertures pedologiques, cartographie, et taxonomie. Science du Sol 4(3): 227-243.

2. Bilasco S, Cocean P, Nicula G, Dragan M (2013). Morphometric limitations to spatial planning in the Arieş Basin. Geographia Napocensis, Year VII (1).

3. Florea N, Buza M (2003). Pedogeographic with notions of pedology. Ed. Lucian Blaga, Sibiu

4. Irimuş I A, Vescan I, Man T (2005). Tehnici de cartografiere monitoring și analiză G.I.S. Ed. Casa Cartii de Stiinta:85-110

5. Pacurar I (2005). Pedologie si statiuni forestiere. Ed. Risoprint:180-215

6. Pacurar I (2012). Studiu pedologic privind evaluarea capacității de suport a zonelor afectate de pășunat cu pajisti alpine si subalpine din Parcukl National Muntii Rodnei: 28-52

7. ***Soil Survey Division staff (1993), Soil survey manual USDa handbook No 18, Washington DC

8. *** I.C.P.A (1987). Development methodology soil studies Vol III, București.

9. *** Management plan of Rodna Mountains National Park (2013). 